\title{
Inflation Misinformation and Monetary Policy
}

\author{
LAWRENCE S. DAVIDSON
}

Consmaer prices, held back by the recession and another arop in gasoline and arpaces, rese only two-tenths of one percent in Februar from dantary's level, continning the sharp decline in the infation rate. . . It shows a steady dedine in infation over the past several months.

T. HE above except is a perfect example of misin formation, at problem that stems from confusing the measurement of price change with the measurement and causes of inflation. The fallure to distinguish the symptoms - like changing gasoline prices - from the causes of inflation can lead to serious policy errors.

This article presents evidence to support the hypothesis which states that efforts to counteract shont-term price changes generally are unnecessary and counterproductive. ${ }^{2}$ We begin by anatyzing the behavior of the individual components of the personal consumption expenditures index to determine the "causes" of observed quarterly changes in the

Lawence S. Davidson, an assactite pafessor of business economies and public policy at Indiate University, is at visiting scholu at the fredenal heserve Bank of St. Loris.

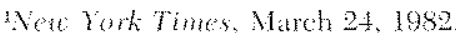

2This does mot imply, hawerer, that such price changes do not

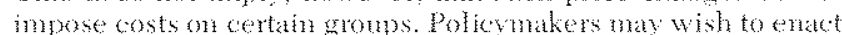

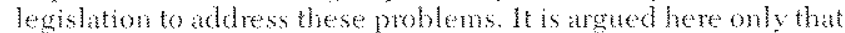

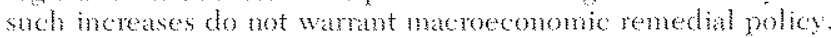
Alan Blinder comes to the same contusion: "From the matco perspective, the volitility of the CPI ofen distrats attention

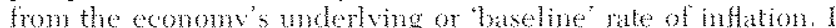
speculate that exeme kwings in the Cor infation rate occitsionally contribute to extrene swing in ational economic polixy, Alan Blinder, "The Consmmer Price ludex and the

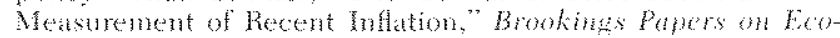

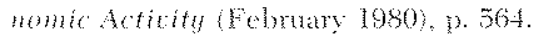

average price level. We then analyze the perfomance of a varable series constucted to approximate the cyclical or nontrend movements in the measured inflation rate. An analysis of this series reveals why the public should be reluctant to pressure policymakers into reacting quickly to even large shont-rin changes in the measured inflion rate. Finally we present data which suggest that monetary policies to combat short-run changes in the inflation ate rase the risk of increasing the underlying or long-term trend of inflation.

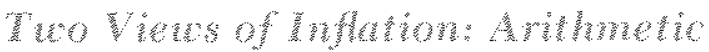

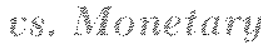

The measurement of inflation necessarily begins with a price index. The most widely known and used index is the consumer price index (CPI), an index of the average price of a fixed basket of goods and services chosen by a typical urban family, The fixedweight personal consumption expenditares price index (PCEI), though similar in most respects to the CPI, is preferable to it in one particular aspect - its treatment of the weight of housing costs. ${ }^{3}$ The important points for our discussion are:

(1) The PCEI is a weighted average of individual goods prices,

(2) The value of the PCEI in any given month can be greatly infuenced by changes in the price of indivithal commodities.

The measured inflation ate is a simple mathematical transfomation of the above price index. For example, instead of sayng that the value of the PCEI rose from 100 to 104 , the inflation rate expresses this

\footnotetext{
"For mote on the problem, sec Binder "The Consamer price
} Inder and the Mevisurement of Rexent Inflation," pp. 535-65. 
price rise as a percentage change. In the above example, we would say that the inflation rate was 4 percent, or $\left(\frac{104-100}{100}\right) \times 100$ percent.

Calculating the inflation rate in this way leads one to the valid conclusion that a large increase in the price of one good (e.g., food) can cause a large change in the value of the PCEI and, therefore, in the measured inflation rate. It is incorrect, however, to say that food prices cause inflation.

This is because the arithmetic view tells only part of the story. Individual prices rise and fall, often in seemingly random and unpredictable ways. Economists call these relative price changes (since individual prices are changing relative to one another). Monetary and fiscal policy are not designed to be effective in changing relative prices. These and other macro stabilization policies are better suited to affect the joint movement of all prices, or inflation.

To understand inflation, we must first distinguish between inflation and relative price changes. Relative prices are determined by the supply and demand conditions in the markets for individual gools. For example, suppose that there were a change in people's tastes that caused them to spend more of their income on recreation and less on durable goods, while other saving and spending plans remaned the same. This change in relative demand should raise the relative price of recreational goods and services while lowering that of durables. Since total spending remains anchanged, the total demand for all goods and services is unchanged; only the allocation of demand across matkets has been altered. Therefore, the overall price level is the same; only relative prices have changed.

If individuals temporarly reduced saving so they could continue purchasing the same amount of durable goods while purchasing more recreational services, then the total dollar demand and the price level would be higher. ${ }^{4}$ Individuals would be acting ats if they were given more income, catusing them to spend more. Once they replenish the ir savings, however, total demand and the price level will retum to thein original lower levels. Thus, a permanent

If all individuals reduced then savings, thete would be lest lomable funds atailable for business investment. Therefore, the increase in consumer spending facilatated by the temporary re dection in saving would be offet by adecline in business soending on mestment goods. Althongh the consumer price index is teriporarily increased, an investment deflator would be lower. A combined measure of werall comsumer and business prices would be unaffected by this change in satving. change in relative demand does not cause sustained inflation, though it does cause permanent changes in relative prices and may cause a temponary change in the price level.

Relative price changes also occur when there are changes in supply conditions. ${ }^{5}$ These include relative changes in labor productivity, wages or other costs associated with the production process. Such changes in a given individual naket can cause the cost-permit to rise, which in tum causes its relative price to rise. With a given income, people who continue to buy the higher-priced item will be forced to spend less on other goods, which puts downward pressure on these prices. "This "cost-push" example hats the same outcome as the relative demand example: relative prices are permanently changed, the price level may change temporarily, but inflation is unaffected.

In the case of increases in the price of inputs like oil, which are used to produce many goods, the increases in the price level may be more pervasive and sustained. If increases in the price of oil are "pushed through," causing the retail price of most goods to rise, individuals whose income has not similarly risen are able to buy fewer goods and services at the higher prices. Both the quantity demanded and supplied are, therefore, lowered. This lower mate of output is permanent unless incomes rise. A tax rebate accompanied by an increase in the growth rate of money could temporarily raise incomes enough to restore demand to the earlier rate of production, but will lead to another increase in the price level as individuals attempt to buy more of all goods.

The point of these examples is that a variety of factors affecting the cost and relative demand structures in individual markets can cause relative prices to change. The constraint that binds the price changes in all the markets is total spending, or income. Withont a commensurate increase in spending, none of these factors can cause all prices to rise, that is, none can lead to a permanent rise in the price index.

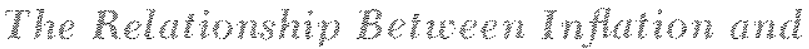

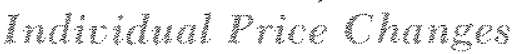

A rise in the measured inflation rate alway hides a great deal of information. The increase may result

\footnotetext{
"For a more detaled explanation of cost push infation, see Dallas S. Batten "1nfution: The Cast-Push Myth," this Retidu (June July 1981), pas. $20-26$.
} 


\begin{tabular}{|c|c|c|c|c|c|}
\hline \multirow[b]{2}{*}{ calegory } & \multirow[b]{2}{*}{ Weight } & \multicolumn{2}{|c|}{$11 / 1959$, v/196? } & \multicolumn{2}{|c|}{11968.41981} \\
\hline & & Mean & $\begin{array}{l}\text { Standard } \\
\text { devation }\end{array}$ & Mean & $\begin{array}{l}\text { Standard } \\
\text { deviation }\end{array}$ \\
\hline Motor vehicles & 1052 & $1413 \%$ & $385 \%$ & $5.06 \%$ & $483 \%$ \\
\hline Fumiture & 045 & 030 & 1/6 & 369 & 256 \\
\hline Other durables & 017 & 127 & 1,69 & 501 & 3,36 \\
\hline Food & 261 & 182 & 237 & 6.96 & 458 \\
\hline elothing & 082 & 166 & 155 & 3.81 & 226 \\
\hline Gas: 8 ol & 031 & 162 & 481 & 10.58 & 1729 \\
\hline fuel oll \& coal & 012 & 101 & 4,33 & 1472 & 2005 \\
\hline Other nondurables & 001 & 178 & 129 & 5,71 & 3.31 \\
\hline Housing services & 137 & 153 & 0.45 & 554 & 184 \\
\hline Housing operations & 060 & 173 & 1.69 & 657 & 324 \\
\hline Transportation services & 037 & 232 & 197 & 733 & 4.82 \\
\hline Personal care services & 019 & 276 & 176 & 715 & 302 \\
\hline Medical services & 058 & 376 & 188 & 764 & 409 \\
\hline Personal ousiness services & 1054 & 339 & 3.44 & 711 & 3.23 \\
\hline Education \& research & 013 & 287 & 166 & 750 & 2.67 \\
\hline Recreation senices & 022 & 353 & 190 & 511 & 188 \\
\hline Religious \& welfare & 015 & 161 & 3,09 & 731 & 366 \\
\hline Net Toreign ravel. & 003 & 1.62 & 5,29 & 767 & 1496 \\
\hline $\mathrm{PeE}$ & 1000 & 185 & 0,98 & 634 & 289 \\
\hline
\end{tabular}

TFigures are averages of annuelzed quarterly rates of change.

from all prices rising together, or merely one price rising by itself. Furthermore, this change may prove to be either temporary or permanent. Policymakers concemed with the causes of and cure for inflation would find this hidden information highly relevant.

Consider the behavior of the individual prices of goods and services included in the PCEI over the past 23 years. Table 1 lists various information about the 18 major categories that make up this index. Because inflation generally has been higher since 1968, the table can be conveniently divided in to two periods: a nine-year period before 1968 and a 14year period afterward. The table shows the mean and the standard deviation for the PCEI and each of its 18 components over both periods. This PCEI is a fixedweight version, which retains the weights from the first quarter of $1959 .{ }^{6}$ The weights are the per-

${ }^{\mathrm{A}} \mathrm{A}$ fixed-weight index is used because variable-weight indices, when used to compare cuarter-to-quater changes, mix together centages of total expenditure allocated to each component.

The measured average yearly inflation rate more than tripled from 1.85 percent in the initial period to 6.34 percent in the latter. The standard deviation, a measure of dispersion around the average, more than doubled. In the 1968-81 period, the annualized quarterly inflation rate averaged 6.34 percent per year, but the average deviation in any particular quarter was about 2.4 percent. This implies that the inflation rate was between 1.5 percent and 11.1 percent, 95 percent of the time. During this period

price and quantity change. The fixed-weight index is a measure of pure quarter-to-quarter price change. Once fixed, no set of weights perfectly captures the buying patterns of the average household over a long period of time. We arbitrarily chose to use weights from the beginning of the sample period. Using weights from the end of the period would not measubly alter the results here. This is becanse the weights have not changed enough on individual price components to change the behavion of the over* all neasured inflation rate. 
(1968-81), selected categories averaged between:7

Housing services: $1.9 \%$ to $9.1 \%$

Motor velicles: $-4.0 \%$ to $14.6 \%$

Fuel oil and coik: $\quad-24.6 \%$ to $54.02 \%$

Fuel oil and coal prices, the fastest-growing consumer prices, averaged over 14 percent per year, followed closely by gas and oil at about 10.6 percent per year. Furniture ( 3.7 percent) and clothing (3.8 percent) were the most slowly growing consumer prices.

The evidence from table 1 suggests that the meaw sured inflation of the recent past is not the result of all prices rising at the same rate each quarter. These figures, however, say very little about the role of particular relative prices as causes of sustained price change. For example, fuel oil and coal prices rose, on average, faster than any of the other prices. But these increases were anything but gradual or persistent. of the 88 quarters from IV/1959 to I/1981, the inflation rate of fuel oil and coal exceeded the rate of the PCEI only 45 times. That means during 43 of the quarters, fuel oil and coal prices rose more slowly than overall inflation. In 22 of these quarters, the absolute price of fuel oil and coal fell (a negative inflation rate for this category). During these 88 quatters, there was not a single episode when the inflation rate on fuel oll and coal increased for more than four consecutive quarters. This pattem (though not necessarily the magnitude) of volatility is typical of most price components. Chart 1, which presents the growth rates of the PCEI and two of its components, reveals the oscillatory behavior of the PCEI. Note that there has been only one episode since 1959 when the overall PCEI inflation rate climbed consecutively for more than three quarters. More will be said about that episode below.

It is cumbersome to discuss each individual price change and its implications for the measured overall inflation rate. Therefore, we introduce a summary measure of nonproportional or relative price

TrThese confidence intervals assume that cuarterly inflation rate changes are nomally distributed. A nomal distribution roughly means that quarterly inflation rate values fall equally above and below the mean and that most of the valines are close to the mean. The standam devation of a random variable measures how much the se cuarterly infation rate changes differ from the mean valne on the average. The 95 percent conficlence interval contains any observations of the cuarterly inflation ate that are within two standard deviations of the mean. Since the mean and standatrd deviation are respectively 6.34 percent and 2.39 percent, there is a 95 percent probability that the quarterly inflation nate is between 1.5 percent $(=6.34$ percent $-2(2.39$ percent $)$ and 11.1 percent $(=6.34$ percent $+2(2.39$ percent $))$. Similar confidence intervals can be constructed for any of the infation rate series. changes (RELP). The RELP series is constructed as follows: For each quarter, subtract the rate of change of the overall PCEI (which is, by definition, the average inflation rate of all components) from each of the 18 component inflation rates. Then multiply the absolute value of each of these 18 deviations for this quarter by its weight and add them. ${ }^{8}$ This gives the value of RELP for each quarter.

If all prices grow at the same rate, RFLP will equal zero. If, however, a few prices rise significantly faster during the quarter than the rest, the value of RFLP will rise. If these prices then decelerate (and/ or if the others accelerate), so that all prices are again rising more equally, RELP will fall.

As chart 2 shows, the RELP measure has a number of interesting features:

(1) The greatest increases in RELP came in 1972 and 1973 during food prote shocks, during wage and price decontrol and after oil prices antadrupled.

(2) While the value of RFI 1 fell from the end of 1973 until 1978 , it generally averaged a higher value than before 1973

(3) While RELP showed no obvious trend before 1970 , its average value has been rising since then from about 1.62 before 1971 to 3.46 thereafter),

In summary, inflation has been anything but a smooth, upward transition in all prices. It is typified by a few prices racing ahead of the others, then falling back relatively quickly. In one episode, RELP accelerated for seven consecutive quarters, but this was an unusual period, typified by a series of food supply shortfalls, wage and price decontrol and, finally, the oil crisis.

One implication of this evidence is that individual price changes have a significant - albeit temporary

The same category weights ased to construct the overall PCEI ate used here.

"While we have noted how RELP arithmetcally "causes" price change, others have argued that increases in the inflation rate have caused higher levels of relative price change. One can see from chart 2 that there is a correlation between the average percentage change in the PCEI and the average value of RELP. The implication of this finding is that higher average inflation rates, which raise the value of RELP, increasingly confuse economic agents and rase the likelihood of reduced output and higher unemployment rates. See, for example, Mario I. Blejex and Leonardo Leideman, "On the Real Effects of Inflation and Relative Price Variability: Some Empirical Evidence," Review of Economics and Statisfics (November 1980), pp. 539-44; and Milton Friedman, "Nobel Lecture: Inflation and Unemployment," Journal of Political Economb (June 1977), pp. 451-72. 
Chart 1

Growth Rates of the PCEI and Two Components

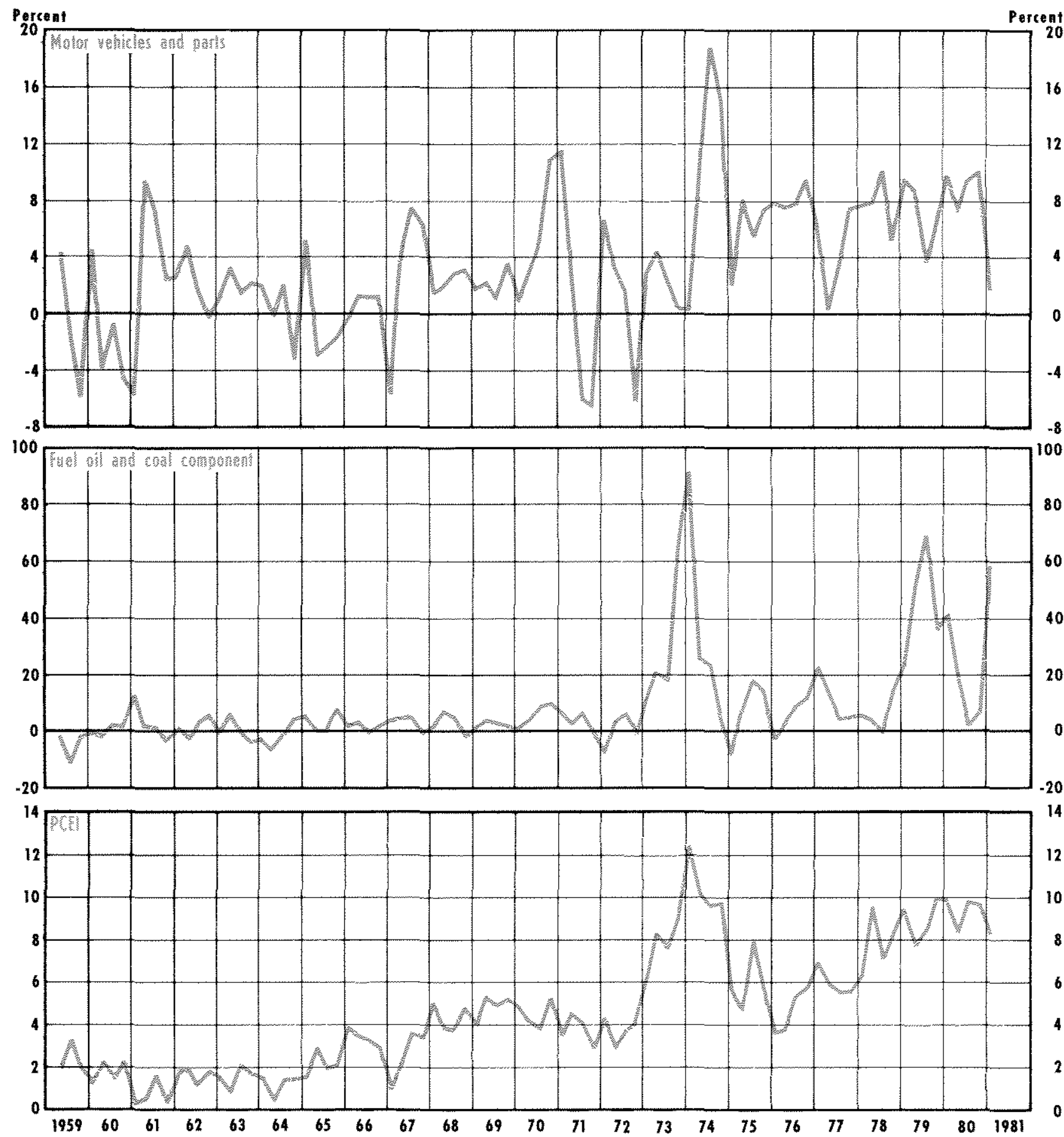


Chark 2

\section{Relative Price Change and the Average Inflation Rate}

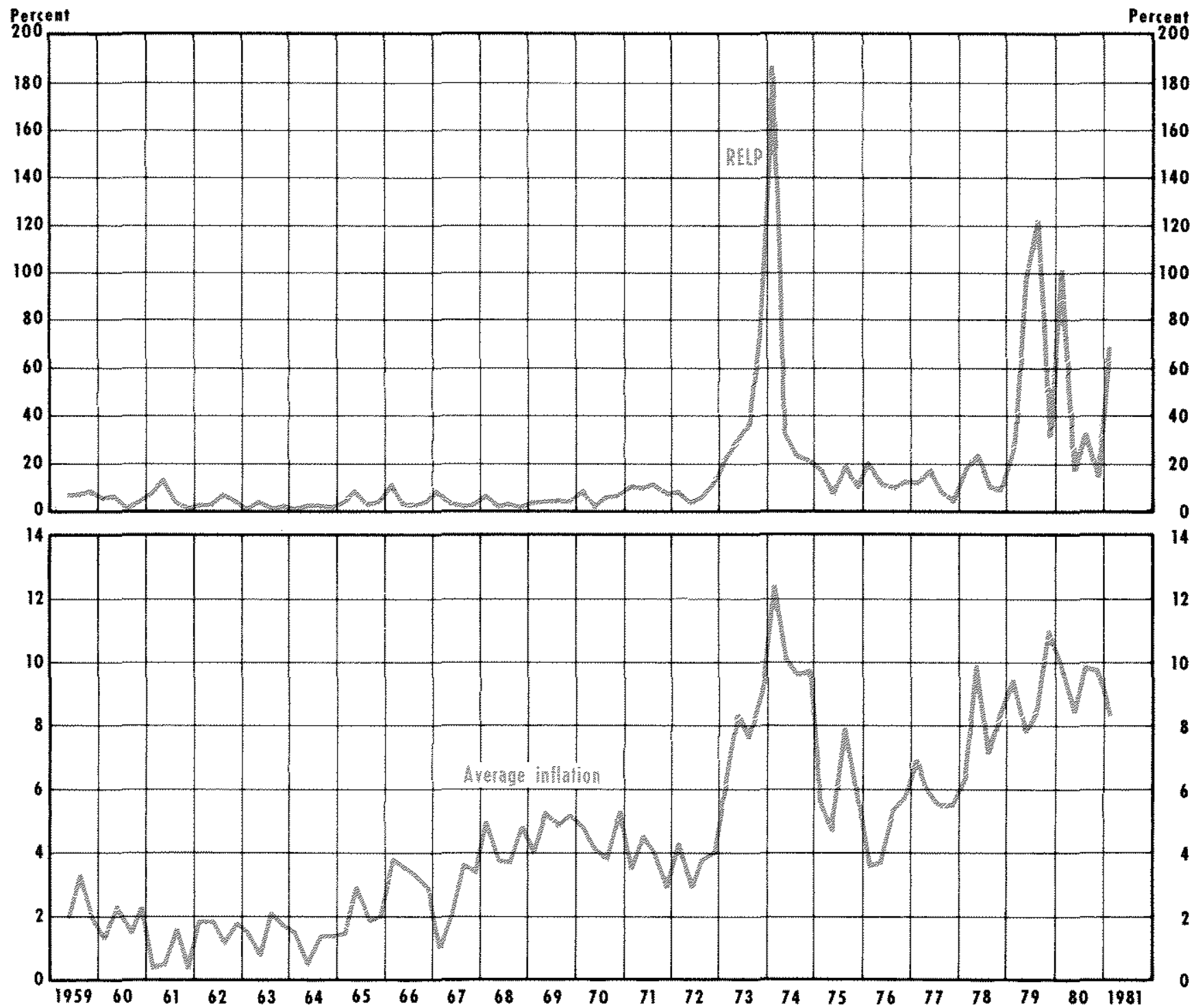

- impact upon overall changes in the measured inflation rate. This finding has important policy content. Macroeconomic policies, which are designed to affect incomes or spending, are not efficient devices for combating the frequent and quickly reversible relative price changes. Therefore, policy aimed exclusively at stabilizing all changes in the inflation rate will be unproductive. It may even be counterproductive if the relative price changes are both highly unpredictable and transient.

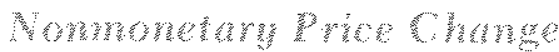

Monetarists have argued that the dominant determinant of sustained spending change is money growth. Therefore, they say, it is primarily sustained money growth that produces inflation (a sustained increase in the prices of all goods and services).

Past studies have found that the underlying inflation rate is significantly related to past growth rates 
of the money supply ${ }^{10}$ Carlson finds that, since the 1970 s, about 12 quarters of past monetary growth translate into an equal sustained change in the inflation rate. Thus, we assume that a simple 12 -quater moving average of money grow th rates approximates the monetary influence on sustained inflation. ${ }^{11}$ For example, if this moving average rate equals 4 percent, then we assume that money is responsible for an underlying inflation rate of 4 percent in a given quarter. If the inflation rate actually is 6 percent in that quarter, then the residual 2 percent can be attributed to nonmonetary causes of price change.

Monetarists also believe that there are numerous sources of price change, yet only changes in money growth can permanently alter the rate of inflation. Therefore, we expect that nonmonetary factors will sometimes affect short-term measured inflation rates. If these nommonetary sources of measured inflation arise unexpectedly over time, and if they only temporarily affect the inflation rate, then the only lasting, predictable and controllable source of inflation would be monetary growth.

One way to determine if the monetary explaration of inflation is valid is to examine the impact of nonmonetary influences on price changes to see if they have any long-run influences on inflation. To do this, we define nommonetary price change as the measured inflation rate of a given quarter, minus the 12-quarter moving average of money growth rates. We then examme the behavior of this series (referred to as PDEV) and the changes in it (henceforth called $\triangle$ ). The monetarist view of inllation would be supported by a variety of evidence about PDEV and $\triangle$ :

(1) If changes in nommonetary inflation, $\Delta$, are temporary, then positive values of $\triangle$ soon would be followed by negative ones. Accordingly, PDEV would rise and then fall toward its original value.

(2) If the increases in $\triangle$ are totally reversible, then over the sample period the sum of the negative $\Delta s$ would be exactly equal to the sum of the positive

\footnotetext{
"Keith M. Carlson, "The Lagr fom Money to Prices," this Retiet October 1980), 12, 3-10, and Denis S. Kamosky, "The Link Between Money ind Prices: 1970-76," this Reciew (June 1976), pp. 17.23.

iThese studies of money and prices use econometric methods and employ distributed lag functions. Fu thermore, these relationships have been fomd using the overall gross national product defator. Therefore, this 12-cluarter moving averuge is only a rough approximation of the influence of money on the trend rate of inflation. However, this moving averuge as well ats longer moving averages and ecomonetric proxies behave cuite similaty and therefore the cualitative findings here would not be seriously changed by using these other measures. See footnotes 13 and 16 for more detals on one econonetrio variant.
}

ones. Therefore, the average value of $\Delta$ would be zero.

It is important to note that this discussion does not imply that the average value of PDEV is zero. The average value of PDEV need not equal zero for two reasons. First, the theory discussed here suggests that monetary growth affects the average of all prices. This does not mean that money grow th is the source of all changes in consumer goods prices as measured by the PCEI. Second, there are factors that affect the rate of inflation for some time without being a constant source of its variability. For example, the trend rate of growth of labor force productivity may keep the inflation rate above or below any given sustained monetary growth rate for some period of time. ${ }^{12}$

(3) Even if $\triangle$ were transient and totally reversible, there could be room for policy action if it were predictable. This would give policymakers time to formulate a policy. According to the monetarist view, negative $\Delta s$ will follow positive ones. This relationship, however, should not allow for reliable predictions of $\triangle$ over time.

Chart 3 presents PDEV and its change, $\triangle$. From 1959 to 1981 , PDEV and $\triangle$ averaged -0.09 and 0.01 , respectively. Prior to 1973 , PDEV was generally negative; thereafter it was positive. The overall and subperiod averages are show in table 2 .

Judging from the average value of $\mathrm{PDEV}$ in the two subperiods, money growth does not fully explain the average inflation rate in either period. In the earlier period, inflation was 0.87 percent below the 3.56 percent growth rate of money. From 1973 to 1981, however, inflation was 1.21 percent above the 6.42 grow th wate of money. ${ }^{13}$

\footnotetext{
12One measure of lator productivity is output per hour of all persons in the private busmess sector. After increasing at a 2.9 percent annmal rate from 1961 to 1971 , it rose at only a 1.2 percent annual rate fon $197 \mathrm{I}$ to 1980 .

${ }^{13} \mathrm{As}$ a check on these results, an alle mative proxy tor PDEY was developed. In this case the monetary contribution to inflation is estimated from an exonometrie price equation. This equation relates the percentage change in the PCEI to a 2 -citarter Almon lag on grow th rates of M1, contemporaneous and wo lag values of relative energy prices, and two dummy variables for the control and decontrol phases of the Nixon wage-price controls. PDEV is calculated by subtracting from the actual rate of change of the defator its predicted walue based only on the monetary part of the estmated equation.

The average value of PDE $V$ from 1959 to 1981 is $.09 \%$, very close to the 090 value of the variant reported in the text. The values of PDEV over the early and later subperiods are -.54 and 50 , respectively. This version of PDEV suguests at smatler, but otil evident, contribution of nonmonetary fitetors to the measured inflation rate over the two sulpperods.
} 
Chant 3

Measures of Nonmonetary Inflation

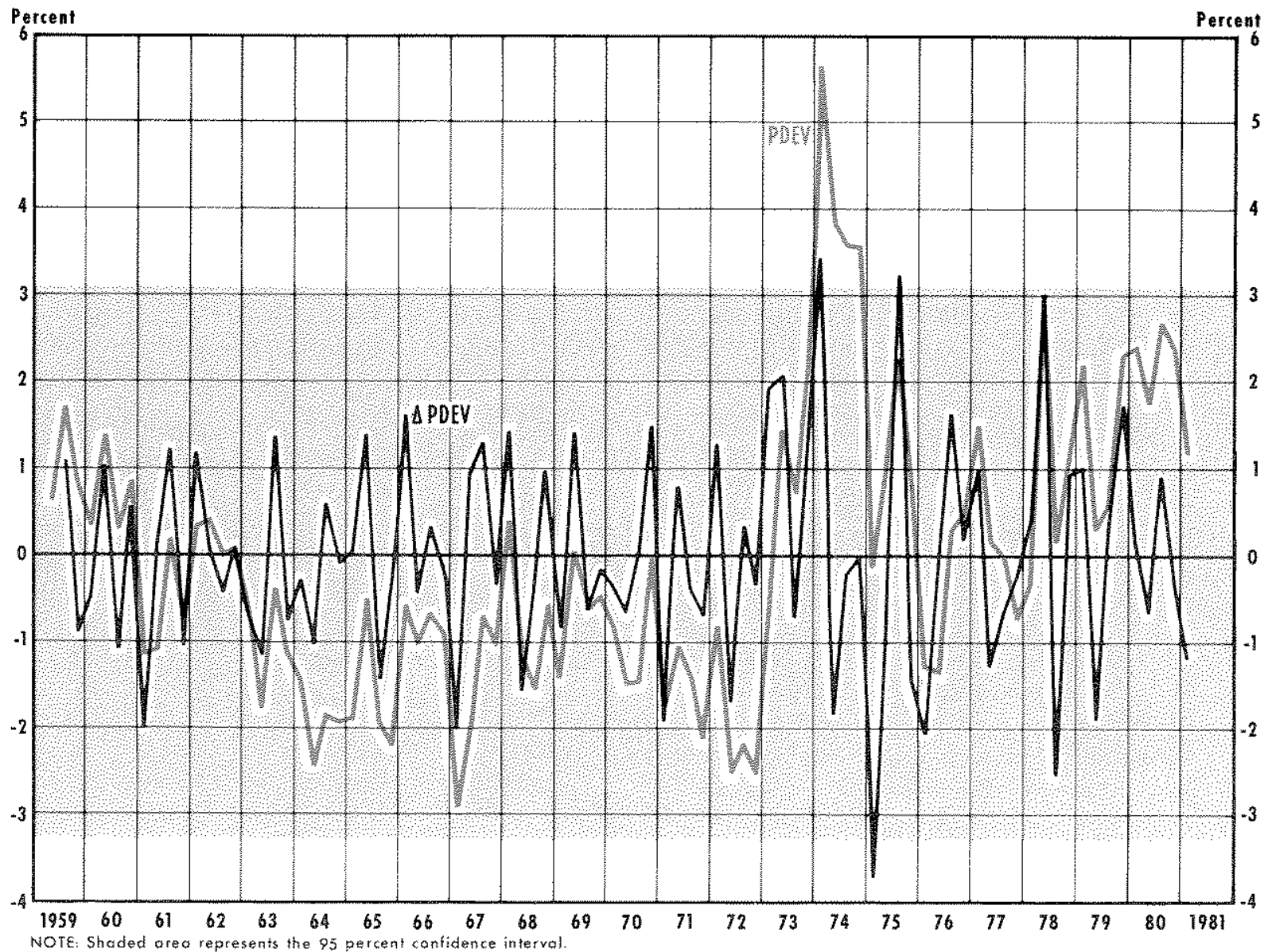

In contrast, the small average values of $\triangle$ in both perods reveal that the average change in PDEV was nearly zero. This suggests that, although factors other than money help to detemine the average level of the inflation rate, short-nunchanges in these nommonetary factors tend to offet one another over time.

Out of 88 quarters, PDEV fell ( $\triangle$ was negative) 45 times. Further, there were 56 times when a rise in PDEV was followed by a fall, or vice versa. Using a statistical test designed to measure the regularity of these changes, we find no significant relationship between $\triangle$ values over time. ${ }^{14}$ This means that changes in the rate of nommonetary price change are

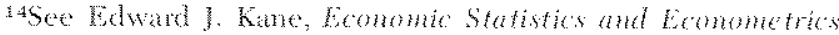

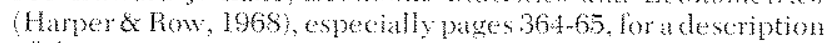
of thes nums test. not correlated with past changes. Thus, persistent nonmonetary effects on changes in the infation rate are not evident, and past values of $\triangle$ are not reliable predictors of fiture ones.

This simple test says nothing about the size of changes in $\mathrm{PDEV}$, espectally over specific episodes within the sample period. We can use a standard statistical procedure to indicate whether any given PDEV or $\triangle$ is worth worying about large enough to be considered a statistically important deviation from zerol. For example, in chart 3 , note that $P D E V$ is less than zero during most quaters prior to 1973 . Is this evidence that nonmonetary factors were holding inflation substantially below the rate dictated by money?

To :tnswer this question, we analyze what might be called "large" "alues of PDEV. Values of PDEV 


\section{Table 2}

\section{Nonmonetary Price Change}

\begin{tabular}{llll}
\hline & $1959-1972$ & $1970-1981$ & $1959-1981$ \\
\hline
\end{tabular}

or $\triangle$ in chart 3 that fall outside the shaded area are evidence that nonmonetary factors caused large price changes. ${ }^{15}$ A number (say three or four) of consecutive quarters of large and rising values of PDE $V^{T}$ or rising $\triangle s$ would be considered evidence of the persistent effect of nommonetary factors on price change.

Chart 3 reveals that the only run of large PDEV values occurred over the four-quarter period from I/ 1974 to IV/1974, ${ }^{16}$ Here, nonmonetary factors contributed to inflation rising significantly faster than money for one year. Another episode, from $11 / 1972$ to IV/1972, which lies near the rejection region, comprises three quarters when inflation grew slower than money. These episodes deserve additional consideration since it could be argued that systematic nonmonetary factors caused sustained inflation above and below the money growth rate.

What happened during 1974 had its beginning in IV/1973 when the prices of fuel oil and coal rose at an anmualized rate of 63 percent, and gas and oil prices

\footnotetext{
${ }^{1}$ Our sample yields only one estinate of the twe mexu of PDFV. The shaded areat in chat 3 is called a confidence interval. This shows by bow much the mean cond vary in repezted somples without refuting that the population mean is zero. "Thus, if we took another independent sample and found a non-zero value for the mean that was inside the confidence interval, it would not refute the hypothesis that the population mean is axro. The areat outside the confidence interval is called the rejection region. If a sample mean lies in this zone, it rejects the hypothesis that the nean $y$ ahe of nommonetary infletion is zeo. By choosing a level of confidence higher than 95 percent, say 99 percent, the area in that 3 would be wider and there would be no rmo of PDE $V$ values in the rejection alat. Lowering the confidence level to 90 percent does not change the results, though there are two episodes that nearly fall into the rejection region: 1/980-IV 1980 and $1 / 1972-1 \mathrm{~V} / 1972$. The forner period witnessed severe of price shocks while the latter, which is discussed more in the text, oecuned during wage anc price controls.

16The econometric varim of PDEV discussed in footmote 13 yields the sane general conelusion: the largest values of PDEV ocsur during 1974. Using this variant of PDEV, however, there is no series of consecutive values of PDEV in the rejection area. This is even stronger evidence than that presented in the text for the transitory natume of changes in nommonetary inflation.
}

increased by 33 percent. In $1 / 1974$ both energy groups again had large annualized rate increases of 91 percent and 63 percent, respectively. These increases, though very large, accounted for only about half of the increase in the measured inflation rate of the first quarter in 1974. In fact 17 of the $18 \mathrm{com}$ ponent prices accelerated - an historical rarity.

By II/1974 the inflation rate of energy items, though still high, was falling dramatically. Judging from food and energy prices alone, the overall inflation rate could have fallen as low as 7.4 percent (from 12.4 percent in $1 / 1974$ ) had it not been for an increase in the relative price of motor vehicles and nondurables (other than food and energy). The overall inflation rate stayed at 9.6 percent in III/1974 and inched up to 9.7 percent in IV/1974 despite the fact that energy prices had leveled off. In the last quarter, the problem appears to be the 12 percent increase in food prices. Given the large weight on food prices, measured inflation could have been down to about 8 percent or less had it not been for this single event.

To summarize, this historical period found nonmonetary sources of inflation persistently greater than zero. It followed, however, on the heels of an umprecedented jump in the rate of increase of energy prices. It appears that within six month the peak nonmonetary effect had been reached. ${ }^{17}$ Further, it appears that events beyond the second quarter of 1974 were separate but adjacent periods of equally bad luck. In the first quarter of 1974, most prices responded to the oil crisis. If the subsequent increases in motor vehicles, nondurables and food prices at various times in the next nine months were related to earlier energy price increases, then we do have a single episode. Even in this interpretation, the bulk of the effect of PDEV occurred within six months, and traces of it were scarce within $12 .^{18}$

The other interesting episode occurred in 1972 when inflation was below the trend growth of money. This episode shows that the more stringent

\footnotetext{
1.7Using very different methods, John A. Tatom, "Energy Prices and Shot Run Economie Perfomance," this Retion (Jantlum 1981) pp. 3-17, also found a very short peak in the inflation rate attributable to energy prices. His econometric nodel of the price level used the CNP implicit price defator and found it to peak within four cuartes after the rise in energy prices.

Whe Labor Depiatment attributed the large morases in food prices over the latst hatf of 1974 to por weather and crop fail ares. See Toshika Nakayma, foloyd E. Wigren and Panl Monsen, "Price Changes in 1974 - An Analysis," Monthly Labor Retio (Tebuary 1975), especially page 15 .
} 
Chart 4

Deviations from Trend of Inflation and Money Growth

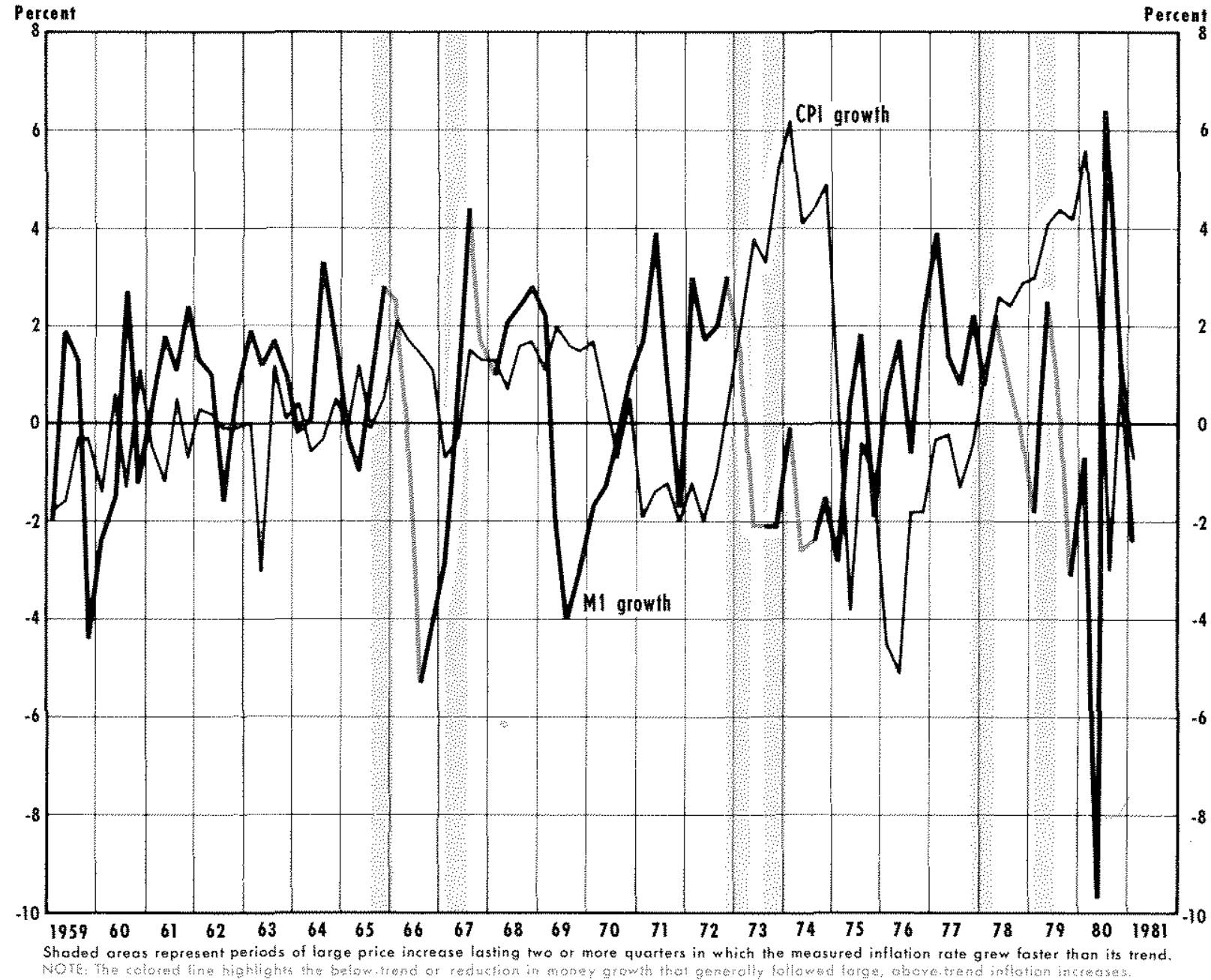

phases of the Nixon wage-price controls effectively kept measured inflation from catching up to trend money growth (which accelerated from about 5 percent at the end of 1971 to 6.5 percent by the last guarter of 1972). It is interesting that when the less restrictive Phase III of the controls began in January 1973, PDEV quidkly tumed positive as prices began to make up for lost ground.

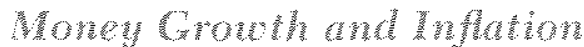 Misinformatom}

The previous sections suggest that the main cause of sustained increases on measured infation is not changes in relative prices. The data presented in this section show that the trend growth rate of money rose from about 2 percent in the early $1960 \mathrm{~s}$ to 7 percent in the early 1980 s. This section suggests that this rising trend stems from an information problem. We alleady have shown that the measured inflation rate often accelerates when relative prices change. If policymakers misread such temporary increases as permanent changes in the inflation ate, they may employ a contractionary monetary policy. We show below that tight money periods nave ustally followed large increases in the measured inflation rate but have been followed by periods of monetary expansion. At the end of eacin cycle, the trend growth rate of both money and prices has been higher. 
Chart 5

Trend Growth Rate of Ml

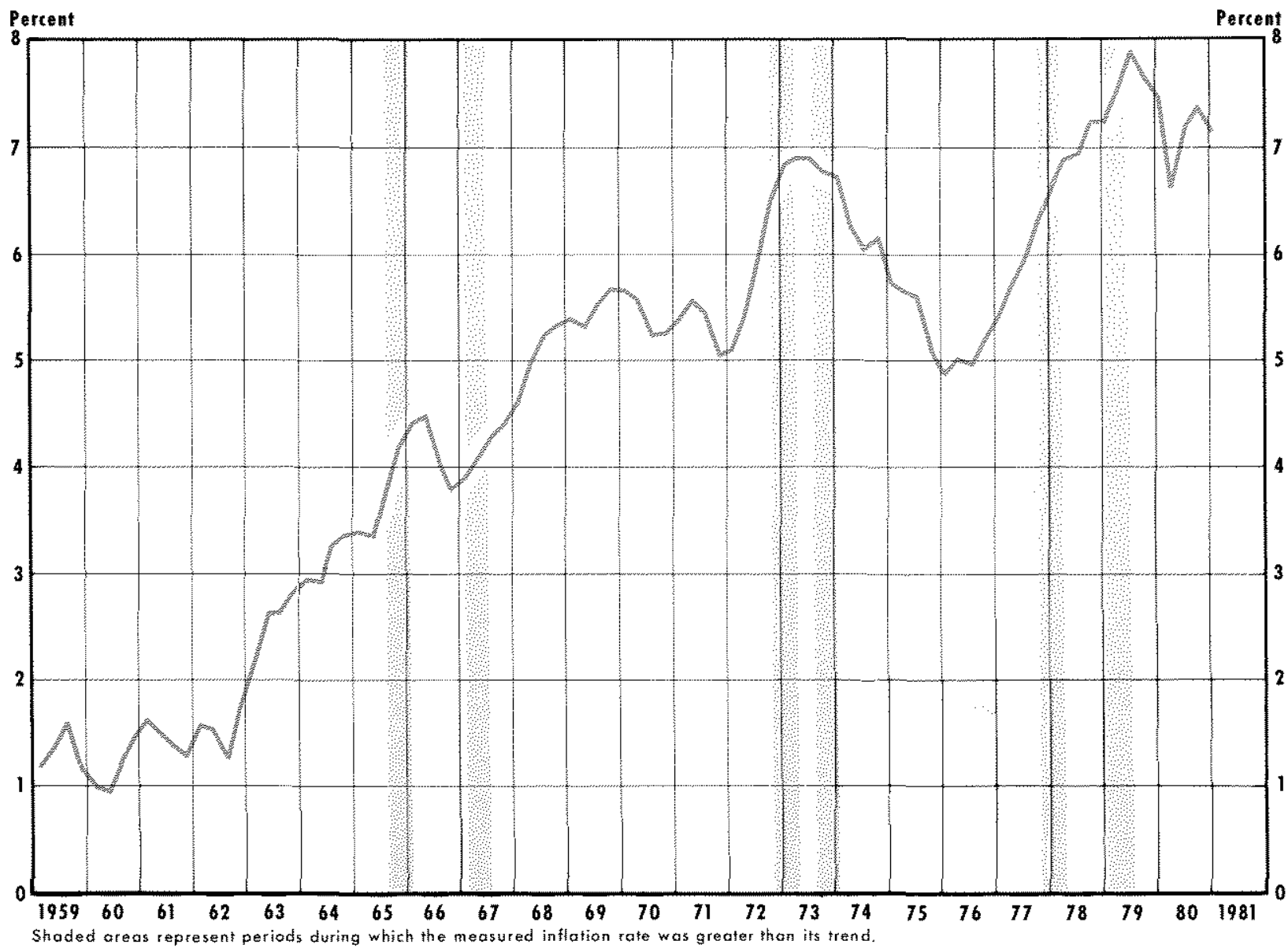

Chat 4 plots the deviations from trend for both the annualized quarterly mates of growth of the CPI and M1. ${ }^{19}$ The shaded vertical bas represent episodes of large price increases, lasting two or more quarters, in which the measured infation rate grew faster than its trend. In each case, we find these above-trend price increases accompanied by large reductions in the grow th rate of money and/or below wend monetary growtin. ${ }^{20}$

\footnotetext{
19 Above we arod that the PCE is a better meanure of price change, and therefore the CPI is not used thonghont this inticle. In this section, however it is important to ase the CPI because it is amosunced more regularly monthly instead of fuaterly) and probably is used more widely. The results in What 4 are not greatly at tered when the PCEI is lsed instead of CPl, since the two generally move together. One importing exception occumed during the first two quarters of 1979. The rate of change of the CPl increased in woth chatuters; the rate of change of the PCEI fell. The refore, if the PCE were ased in the andysis in the text the re wotd be one less historical episede when measured infation rose in two or more consecutive quaters.
}

These reductions, however, were generally of short duration. Chat 5 preserts the 12-quarter moving average of the annalized percentage change in M1. The shaded vertical bars refer to the same periods of large price increase as those in chart 4. Chat 5 shows that the contractions in money fol-

20The theme of this article is that all short-tem changes in pulslished indices of prices fo not demand policy responses. The evidence, however, suggests that monetary growth has fallen after large shertem measured price increases. This does not imply that monetary policy is solely detemined by price changes or that it al ways responds of them. The behavior of money is determined by several factors, and to argue that all monetary changes are attributable to price change wonld be incorret. The evidence doessugest, however, that lares shot term increas's in measured inflation above its 12 -quater trend have been associated with subsequent arge short-term docreases in the rate of growth of monev below its 12 anduter trend. Stanleg Frischer," Relative Shodks, Relative Price VariWhility, and Infation," Brokkines Palues on Economic Acticity (Febriary 1981), pp. 381-431, in an econometric investigation, also fuds evidence that monetary contractions trail inflation surges follow ing relative price shocks. See espectal y page 408. 
lowing these large price increases generally had only temporary effects on the trend growth rate of money and therefore on a variety of measures of inflation.

These abrupt contractions in monetary growth generally have been offset by subsequent monetary expansions. Furthemore, these variations in monetary growth have had severe side effects. Poole finds that monetary decelerations generated recessionary conditions in the United States. ${ }^{21}$ Batten and Hafer come to the same conclusion in their analys is of the impact of short-rin money growth in the United States, Britain, West Germany and Italy. ${ }^{22}$

\section{SUMMARE AND CONCUUSTONS}

This article provides evidence of an information problem inherent in policies that respond to observed changes in the measured inflation rate. The evidence is not inconsistent with the theory that short-rim bouts of tight money follow short periods

2Eilliam Poole "The Relationship of Nonetary Deceleations To Business Cyole Peaks: Another Look at the Fridence,"

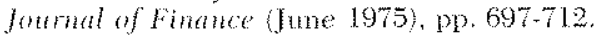

zadalas S. Batten and R. W. Hafer, "Shorthan Money Growth Finctuations and Real Fecomonic Activity: Some Implications for Monetary Targeting, this Revew (May 1982), ps. 15-20. of rising inflation, help to quickly generate recessionary conditions, lead to subsequent longer periods of expansionary monetary policy and result in a rising trend growth rate of the money supply. The information problem that sets off these cycles is the misinterpretation of increases in measured price change as sustained inflation. We have provided evidence that nommonetary sources of measured infation are frequent, highly variable and quickly self-reversible. Therefore, employing policy to offset these individual shocks is difficult to accomplish or to justify.

This analysis has broad implications for policymakers. First, short-term changes in measured inflation do not call for an activist monetary policy. Second, a policy of steadily declining monetary growth will contribute to more economic stability, while it reduces the underlying rate of inflation. Finally, there is a need to distinguish the nature of the causes of individual bouts of price change as the first step in policy formulation. A sustained increase in the rate of change of all prices, once uncovered, is important information which policymakers can use to guide monetary and fiscal policies. Of course, the evidence reported here suggests that policymakers could ignore short-run measurements of inflation altogether by simply concentrating on the appropriate long-term monetary target.

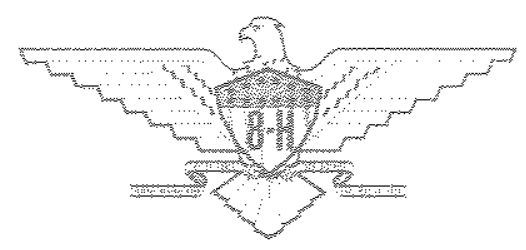

